Original Research Paper

\title{
Determination of Mercury and Manganese by Using New Reagent Azo after Cloud Point Extraction for Some Environmental Sample in Iraq
}

\author{
Saadiyah Ahmed Dhahir \\ Department of Chemistry, College of Science for Women, University of Baghdad, Baghdad, Iraq
}

Article history

Received: 28-02-2015

Revised: 24-07-2015

Accepted: 19-09-2015

\begin{abstract}
A new reagent of Azo was papered for determination of $\mathrm{Hg}^{+2}$ and $\mathrm{Mn}^{+2}$ by Cloud Point Extraction (CPE) method. Procedure which was developed for the separation and preconcentration and the procedure are simple, cheap, fast and environmental safety. The parameters affecting could point extraction, such as concentrations of reagent, volume of triton $\mathrm{X}-100, \mathrm{pH}$, equilibrium of temperature and time-consuming were studded. Under the optimum condition the linear range 2-14 $\mu \mathrm{g} \mathrm{L}^{-1}$ for mercury and 2-16 $\mu \mathrm{g} \mathrm{L}^{-1}$ for manganese at $\mathrm{pH}$ 7. The detection limit was $0.75,0.4$ $\mu \mathrm{g} \mathrm{L}^{-1}$ and relative standard deviation was $1.3 \%, 1.4 \%$ respectively, the recovery of analytes was found $96-98.7 \%, 97-99.7 \%$. The method was applied to the determination of manganese (II) and mercury(II) of wastewater of Rustimiyah city in Iraq.
\end{abstract}

Keyword: Cloud Point Extraction, 3-[(5-Hydroxy-3-6, 6Trimethylclohexa2,4-Dienyl)Diazenyl]Phenol, Determination Mercury and Manganese

\section{Introduction}

Almost all mercury compounds are toxic and can be dangerous at very low levels in both aquatic and terrestrial ecosystems. Because mercury is a persistent substance, it can build up ( $\mathrm{Li}$ and $\mathrm{Hu}, 2007)$. Mercury and mercury compounds are some of the most regulated of all chemicals. The Environmental Protection Agency (EPA) is responsible for regulating discharges of mercury and mercury compounds into the environment (atmosphere, waters and landfills) (Scarmoutzos and Boyd, 2004). Manganese has been called as a rare element; it was found a trace amount in human body more than it is important in biochemistry which plays as co-factor for several enzymes and plays a role in establishing tissue (Velasco-Ryenolda et al., 2008), fat and bone. The low concentration of metal ions in sample and the matrix interference which requires sensitive apparatus techniques, pr-concentration, separation such as liquid-liquid extraction (Roundhill et al., 2009), solid phase extraction (Yang et al., 2004), last decade use cloud point extraction (Manzoori and Bavili-Tabrizi, 2002). Different reagent of azo and Schiff base use to determination ions by (CPE) method such as 1-(2thiazolylazo)-2-naphthol(TAN)(Chen and Toe, 2001), 2(5-bromo-2pyridylazo)-5-diethylaminophenol(5-BrPADAP) (Wuilloud et al., 2008), -(2-thiazolylazo)-pcresol (TAC) (Portugal et al., 2007), (2-pyridylazo) resorcinol (PAR) (Doroschuk et al., 2004), PMBP (Manzoori and Abodlmohammad-Zadeh, 2007) and Schiff base such as N,N'-bis (salicylidene) ethylenediamin [SALEN] (Bakir and Dhahir, 2013), E-4(3-hydroxybenylideneamino) 1,5 dimethyl-2-phenyl1Hpyrazol- 3(2H)-one[4-(HBDA1), 5DPHPO] (Dhahir and RhajabBakir, 2015), Bis((1H-benzo[d]imidazol-2yl) methyl) sulfane[BHIS] (Ahmad et al., 2011), Nsalicylideneaniline (SA) (Youcef et al., 2006).

\section{Instrumentation and Apparatus}

\section{Instruments}

A thermo stated water bath model Memmert, UVVisible model HACH, FTIR Shimadzu, model IRPRESTIGE 21, Japan, PH meter HANNA 211, Phase separation was achieved with centrifuge TG-04S TABLE-TOP of $4100 \mathrm{rpm}$. 


\section{Regents}

All the chemicals used were of analytical reagent grade; deionize water use to diluting the samples. Hydrochloric acid (BDH), Triton X-100 (Merck), Sodium hydroxide (BDH), sodium nitrate (BDH), thymol (BDH), ethanol (Merck), manganese sulphate mono hydrate (GCC), 3-amino phenol (BDH). About $1000 \mu \mathrm{g} \mathrm{L}^{-1}$ stock solution of $\mathrm{Mn}^{+2}$ and $\mathrm{Hg}^{+2}$ were prepared by dissolving $0.1353,0.159 \mathrm{~g}$ of mercury(II) chloride and manganese sulphate mono hydrate an appropriate amount of deionized water and diluting to the mark in $100 \mathrm{~mL}$ volumetric flask. Working stock solution was prepared daily from the stock by appropriate dilution with water. Stock solution of HTMCDAP reagent was prepared by dissolving 0.258 $\mathrm{g}$ in $0.5 \mathrm{~mL}$ of $10 \%(\mathrm{~V} / \mathrm{V})$ TritonX-100 and diluting to the mark in $100 \mathrm{~mL}$. Non-ionic surfactant, TritonX-100 $10 \%(\mathrm{~V} / \mathrm{V})$ was prepared by dissolving $10 \mathrm{~mL}$ Triton $\mathrm{X}-$ 100 in hot deionize water and diluting to the mark in $100 \mathrm{~mL}$ volumetric flask. $0.01 \mathrm{M}$ hydrochloric acid and $0.01 \mathrm{M}$ sodium hydroxide use to adjust $\mathrm{pH}$.

\section{General Procedure for CPE}

Aliquots $10 \mathrm{~mL}$ of a solution containing a known amount of $\mathrm{Mn}^{+2}, \mathrm{Hg}^{+2}$ ions, $10 \%(\mathrm{v} / \mathrm{v})$, Triton $\mathrm{x}-100$ and reagent was adjusted the $\mathrm{pH}$ by $0.01 \mathrm{M} \mathrm{HCl}, 0.01$ $\mathrm{M} \mathrm{NaOH}$. The mixture was shaken for $1 \mathrm{~min}$ and left to stand in a thermo-stated bath at $70^{\circ} \mathrm{C}$ for $15 \mathrm{~min}$. Separation of the phases was achieved by centrifugation at $4100 \mathrm{rpm}$ for $15 \mathrm{~min}$ the remaining of micelle phase was dissolved by ethanol, $\mathrm{Mn}^{+2}$ and $\mathrm{Hg}^{+2}$ ions were measured by UV-Vis spectrophotometer at $\lambda_{\max } 444$ and $423 \mathrm{~nm}$.

\section{Synthesis and Characterization of Reagent}

The synthesis of 3-[(5-hydroxy-3-6,6trimethylclohexa2,4-dienyl)diazenyl]phenol scheme(1) was synthesized according to the reported method by dissolved $3 \mathrm{~g}(0.027 \mathrm{~mol})$ of $\mathrm{C} 6 \mathrm{H} 4(\mathrm{NH} 2)(\mathrm{OH})$ in $5 \mathrm{~mL}$ of concentrated hydrochloric and $5 \mathrm{~mL}$ deionized water and diazotized below $5^{\circ} \mathrm{C}$ with $(0.75 \mathrm{~g}, 0.01$ mol) of sodium nitrite. The resulting diazonium chloride solution was added drop wise with cooling to solution of thymol $4 \mathrm{~g}(0.026 \mathrm{~mol})$ dissolved in $5 \mathrm{~mL}$ of alkaline ethanol; the solid product was filtered and crystallized from hot ethanol.

\section{Results and Discussion}

\section{The FTIR Spectrum of Ligand HTMCDAP and Complexes}

The FTIR spectra of free ligand showed an appearance of broad band's at $\left(1438 \mathrm{~cm}^{-1}\right)$ refer to the frequency of azo group confirmed that a synthesized dye containing azo group (Veerachalee et al., 2007). Table 1 and Fig. 1 showed the broad bands of ligand HTMCDAP in KBR disk.

The FTIR spectra of free ligand showed two bands at $\left(3429,3178 \mathrm{~cm}^{-1}\right)$ refer to the frequency of $v(\mathrm{OH})$ of phenolic group respectively, while in the metal complexes observed that the disappearing of one band for $v(\mathrm{OH})$ vibration in the spectra of $\mathrm{Hg}$-HTMCDAP and Mn-HTMCDAP, indicating the coordination of phenolic oxygen with metal ions (Mohammed and Asniza, 2010). The spectra bands of the free ligands at $1438 \mathrm{~cm}^{-1}$ refer to azo group $v(\mathrm{~N}=\mathrm{N})$ shifting to higher bands in the metals complex's observed at $\left(1458,1454 \mathrm{~cm}^{-1}\right)$. The infrared spectra of the complexes have shown some other new bands which appeared in the range (582-520 $\left.\mathrm{cm}^{-1}\right),\left(594-51 \mathrm{~cm}^{-1}\right)$ and $\left(482-424 \mathrm{~cm}^{-1}\right),(466-405$ $\mathrm{cm}^{-1}$ ) are due to the $v(\mathrm{M}-\mathrm{O})$ and $v(\mathrm{M}-\mathrm{N})$, respectively (Al-Bayati et al., 2013; Nakamoto, 1997) for MnHTMCDAP and Hg-HTMCDAP. Figure 1 to 3 shown the FTIR for Ligand and complex's.

Ultraviolent Spectrum of Ligand HTMCDAP and $H g-H T M C D A P$ and $M n-H T M C D A P$

The UV-Vis spectrum of HTMCDAP shown maximum absorption at $294 \mathrm{~nm}$ due to the $\left(\pi \rightarrow \pi^{*}\right)$, the azo group $(\mathrm{N}=\mathrm{N})$ gives an absorption in the $397 \mathrm{~nm}$ (Kirkan and Gup, 2008). The complex with HgHTMCDAP and Mn-HTMCDAP the maximum absorption were appeared at 444 and $423 \mathrm{~nm}$ while the ligand at $397 \mathrm{~nm}$ maximum absorption. Figure 4 to 6 shown the UV/VIS for ligand and complexes.

\section{C.H.N Analysis}

The results of element analysis of new reagent HTMCDAP were explain in Table 2.

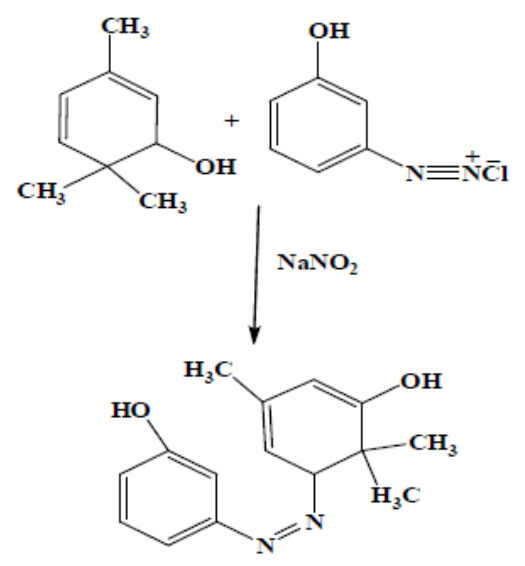

3-((5-hydroxy-3,6,6-trimethylcyclohexa-2,4-dienyl)diazenyl)phenol

Schem 1. The chemical structure of Reagent HTMCDAP 


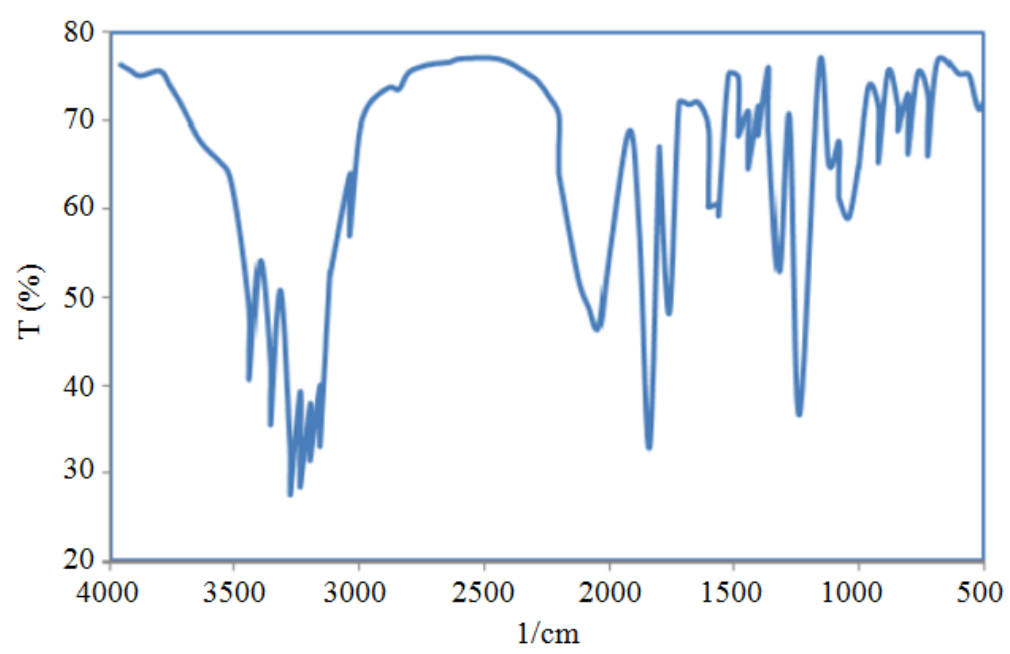

Fig. 1. FTIR of ligand HTMCD

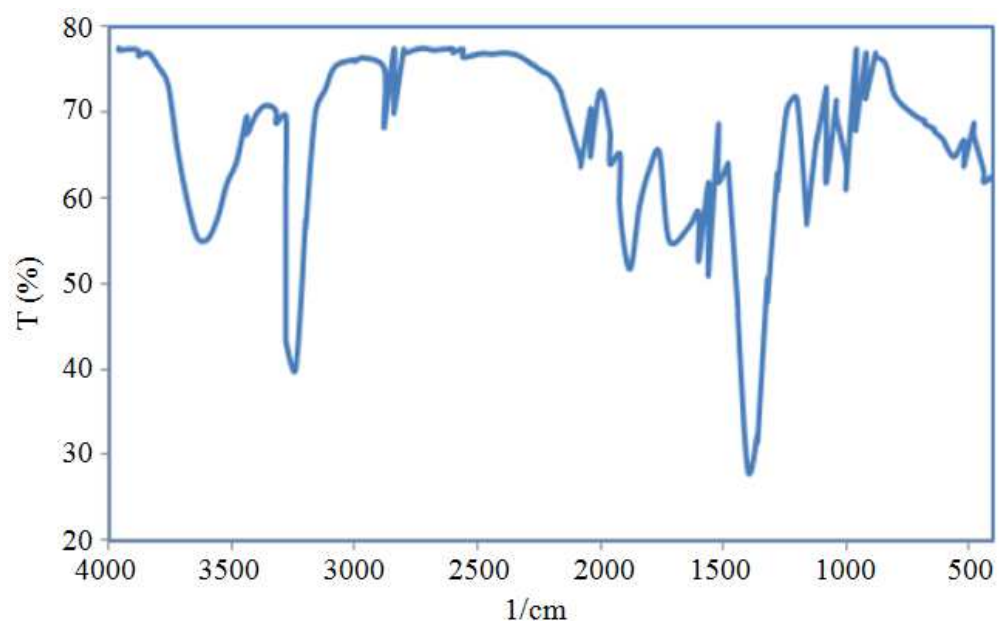

Fig. 2. FTIR of Mn-HTMCDAP

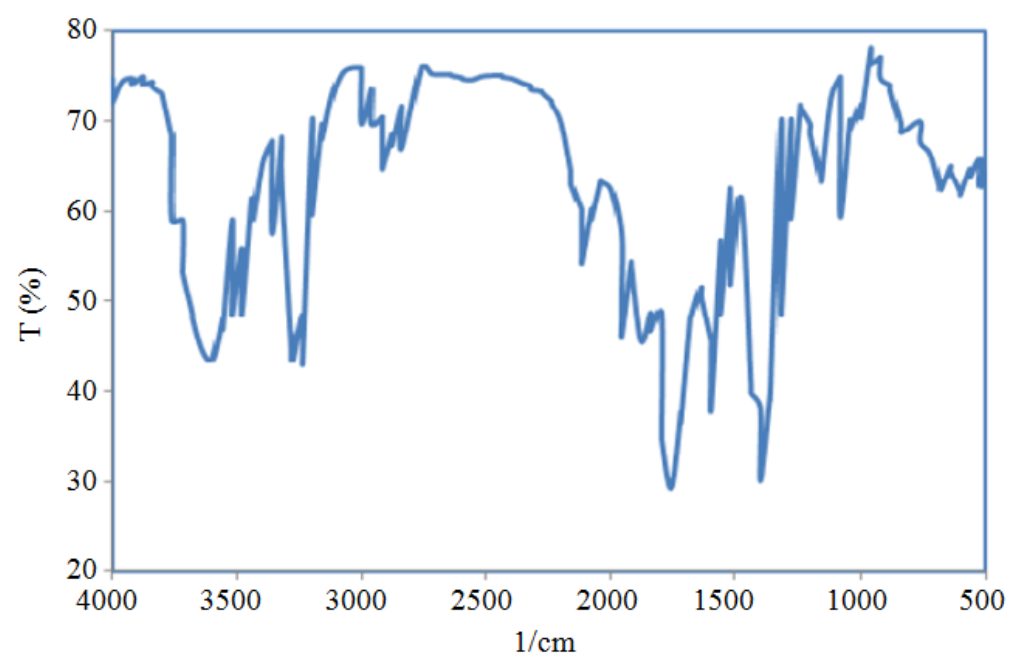

Fig. 3. FTIR of Hg-HTMCDAP 


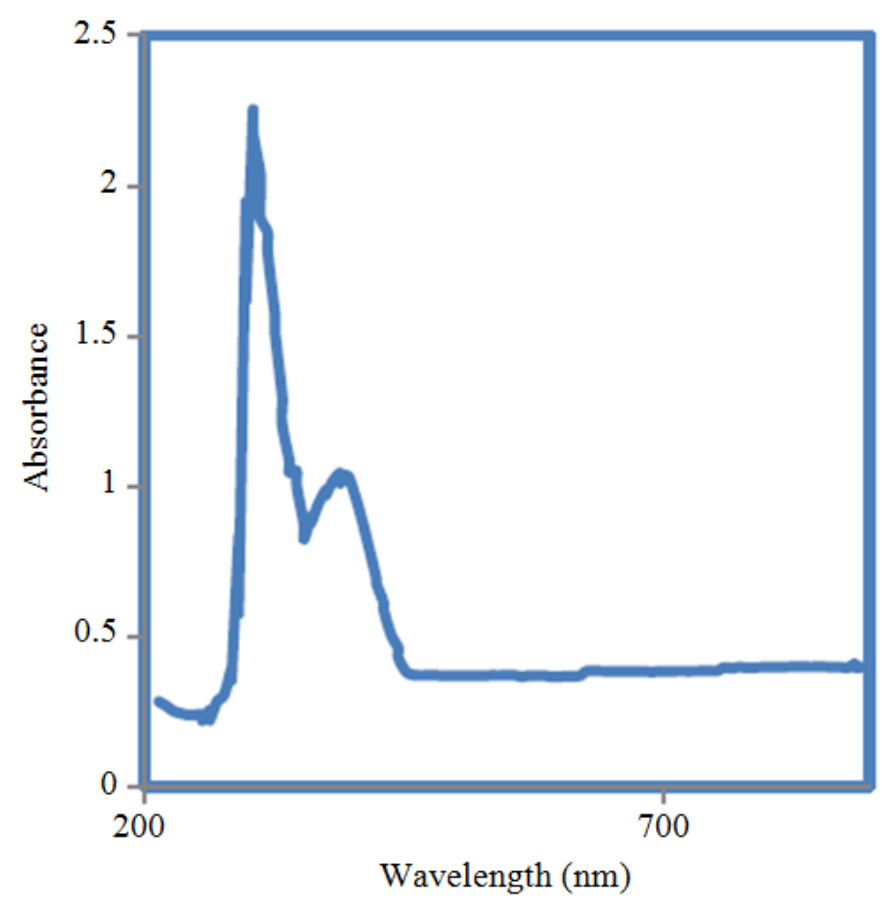

Fig. 4. The spectrum of ligand

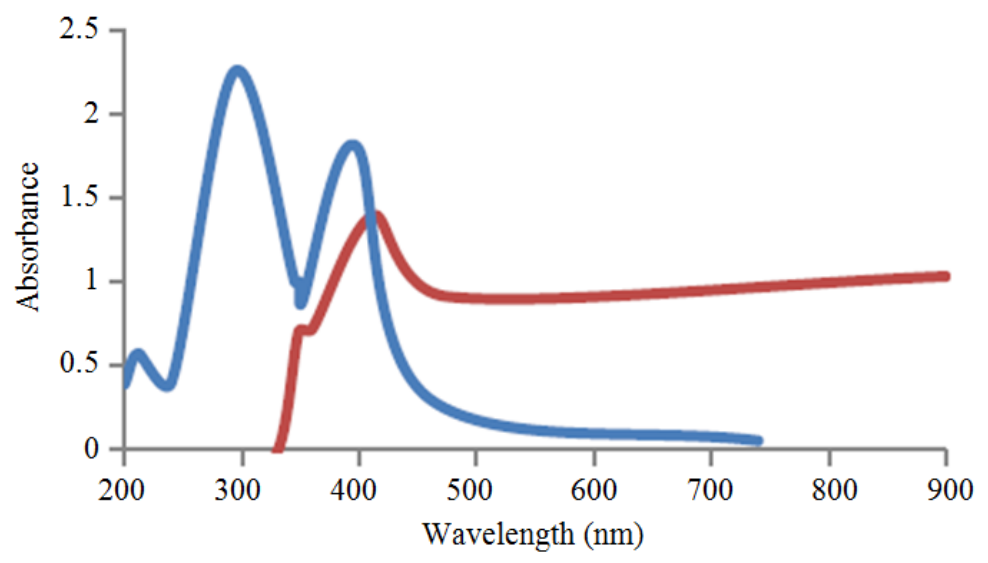

Fig. 5. The spectrum of complex Mn-HTMCDAP

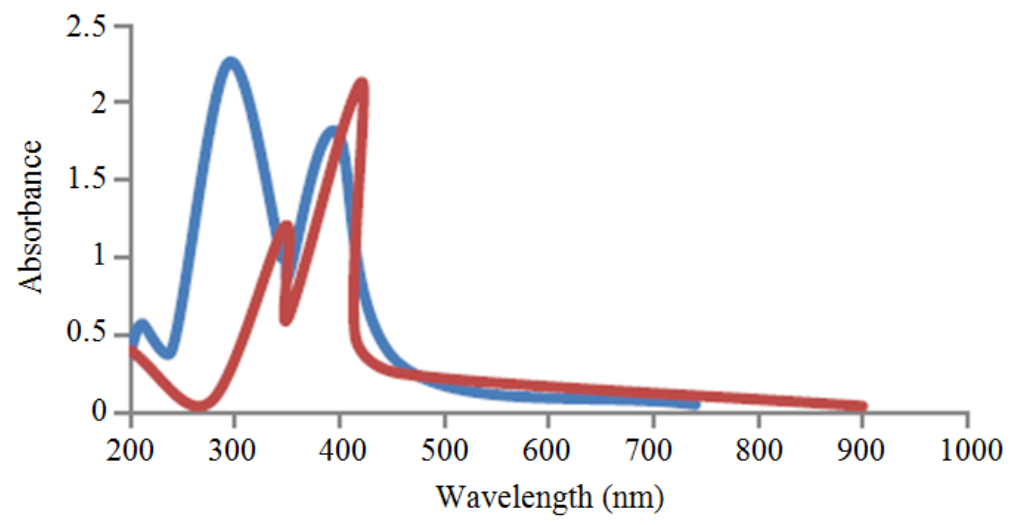

Fig. 6. The spectrum of complex Hg-HTMCDAP 
Table 1. IR data $\left(400-4000 \mathrm{~cm}^{-1}\right)$ of HTMCDAP

\begin{tabular}{lc}
\hline IR bands & ${\text { Wave number } \mathrm{cm}^{-1}}^{\text {O-H stretching }}$ \\
C-H aromatic & $34,293,178$ \\
C-H aliphatic & 3066 \\
$\mathrm{~N}=\mathrm{N}$ & $29,622,924$ \\
$\mathrm{C}=\mathrm{C}$ & 1438 \\
$\mathrm{C}-\mathrm{H}(\mathrm{s}, \delta$, bend aromatic) & 1381 \\
\hline
\end{tabular}

Table 2. Elemental analysis of HTMCDAP by C.H.N

\begin{tabular}{|c|c|c|c|c|}
\hline \multirow[b]{3}{*}{ C } & \multicolumn{4}{|c|}{ Percentage } \\
\hline & \multicolumn{4}{|c|}{$\mathrm{C} 15 \mathrm{H} 18 \mathrm{~N} 2 \mathrm{O} 2$} \\
\hline & $\mathrm{H}$ & $\mathrm{N}$ & $\begin{array}{l}258.32 \\
\mathrm{~S} \\
\end{array}$ & Calculation \\
\hline 69.74 & 7.02 & 10.84 & 0.0 & Theoretical \\
\hline 70.76 & 6.93 & 11.11 & 0.0 & Practical \\
\hline
\end{tabular}

\section{Optimization of CPE Procedure}

\section{Effect of $p H$}

The $\mathrm{pH}$ plays a critical role on metallic complex formation and has been a significant parameter for CPE, the aqueous solutions on the extraction yield of $\mathrm{Mn}^{+2}$ and $\mathrm{Hg}^{+2}$ as HTMCDAP reagent were investigated in the $\mathrm{pH}$ range $4-14$, the maximum sensitivity for $\mathrm{CPE}$ was obtained at $\mathrm{pH} 7$ the results are shown in Fig. 7. In more acidic solutions due to protonation the reagent while in the basic solution due to formation of charged hydroxyl-M-HTMCDAP mixed complexes or precipitation of metal ions in the form of hydroxides. So as the $\mathrm{pH} 7$ was chosen.

\section{Effect of HTMCDAP Concentration}

The concentration of reagent is important indicator as to whether the reagent action processed completely. The effect of HTMCDAP concentration on the absorbance was investigated within range $\left(1 \times 10^{-5}\right.$ $\left.9 \times 10^{-5}\right) \mathrm{mol} \mathrm{L}^{-1}$, the results are shown in Fig. 8 . Shows that the measured absorbance increases when the concentration of HTMCDAP increases and then suddenly decreased up concentration $7 \times 10^{-5} \mathrm{~mol} \mathrm{~L}^{-1}$, therefore $7 \times 10^{-5} \mathrm{~mol} \mathrm{~L}^{-1}$ was chosen.

\section{Effect of Triton X-100 Volume}

Figure 9 has shown effect of surfactant volume on the cloud point extraction of $\mathrm{Mn}^{+2}$ and $\mathrm{Hg}^{+2}$. Different volumes of $10 \%(\mathrm{v} / \mathrm{v})$ Triton $\mathrm{X}-100$ ranging from (0.1-1) $\mathrm{mL}$, the highest absorbance was found at 0.8 $\mathrm{mL}$ of $10 \%(\mathrm{v} / \mathrm{v})$ Triton X-100 up this TritonX-100 volume, the analytical signal starts to decrease. This can be attributed to an increase in viscosity of the surfactant phase. Thus, $0.8 \mathrm{~mL}$ of $10 \%(\mathrm{v} / \mathrm{v})$ Triton X100 was used as optimal.

\section{Effect of Equilibrium Temperature and the Incubation Time}

The effects of the equilibrium temperature and the incubation time are important factors in (CPE) and efficient separation of phases. Absorbance was investigated in the range of $40-95^{\circ} \mathrm{C}$ and $5-35$ see and the results is shown in Fig. 10 and 11. Excellent absorbance was found at temperature $85^{\circ} \mathrm{C}$ for $\mathrm{Hg}^{+2}$ and $70^{\circ} \mathrm{C}$ for $\mathrm{Mn}^{+2}$ at higher temperature could cause decomposition of the complex. It was also observed the maximum absorbance found at 25 and $30 \mathrm{~min}$ for $\mathrm{Hg}^{+2}$ and $\mathrm{Mn}^{+2}$ thus, selected 25 and $30 \mathrm{~min}$.

\section{Interferences Study}

The effect of most diverse ions expected in the wastewater sample of Rustimiyah city in Iraq on the determination of $14 \mu \mathrm{g} \mathrm{L}^{-1} \mathrm{Hg}^{+2}$ and $16 \mu \mathrm{g} \mathrm{L} \mathrm{L}^{-1} \mathrm{Mn}^{+2}$ under the optimal condition, cations may react with reagent and anions may form complex's with $\mathrm{Hg}^{+2}$ and $\mathrm{Mn}^{+2}$ thus, extraction efficiency decreases. Table 3 shown the effect of Interferences ions.

\section{Calibration Graph}

Employing the optimum conditions established by CPE procedure to determination $\mathrm{Hg}^{+2}$ and $\mathrm{Mn}^{+2}$, the calibration graph response to the Beer law over the concentration 2-14 $\mu \mathrm{g} \mathrm{L}^{-1}$ for mercury and 2-16 $\mu \mathrm{g} \mathrm{L}^{-1}$ for manganese with correlation coefficient 0.9982, 0.9961 are shown in Fig. 12 and 13. All other analytical characteristics data are summarized in Table 4.

\section{Continuous Variation Method}

A series of range from 1 to $9 \mathrm{~mL}$ of $7 \times 10^{-5} \mathrm{~mol} \mathrm{~L}^{-1}$ $\mathrm{Hg}^{+2}$ and $\mathrm{Mn}^{+2}$ was pipetted into each of eleven $10 \mathrm{~mL}$ volumetric flask, then $9,8,7,6,5,4,3,2,1 \mathrm{~mL}$ of $7 \times 10^{-5}$ mol L ${ }^{-1}$ HTMCDAP reagent added into each volumetric 
flasks at optimum $\mathrm{pH}$, the absorbance of the solutions were measured by UV-visible spectrophotometer. The stoichiometric ratio between $\mathrm{Hg}^{+2}$ - HTMCDAP and $\mathrm{Mn}^{+2}-$ HTMCDAP is shown in Fig. 14 and 15. Predict structure for the complex is $1: 2$ as shown in scheme 2 .

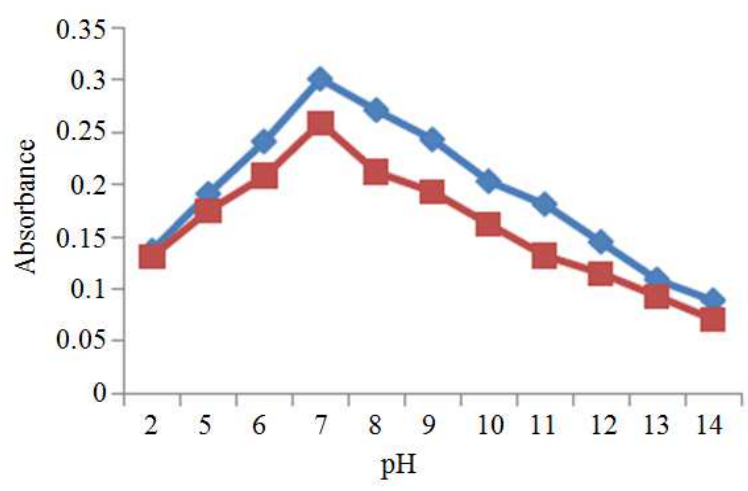

Fig. 7. Effect of $\mathrm{pH}$ on the cloud point extraction of $\mathrm{Mn}^{+2}=16$ $\mu \mathrm{g} \mathrm{L}^{-1}$ and $\mathrm{Hg}^{+2}=14 \mu \mathrm{g} \mathrm{L}^{-1}$, HTMCDAP $=7 \times 10^{-5} \mathrm{Mol}$ $\mathrm{L}^{-1}, 0.8 \mathrm{~mL} \mathrm{10 \%}(\mathrm{V} / \mathrm{V})$ (Triton X-100)

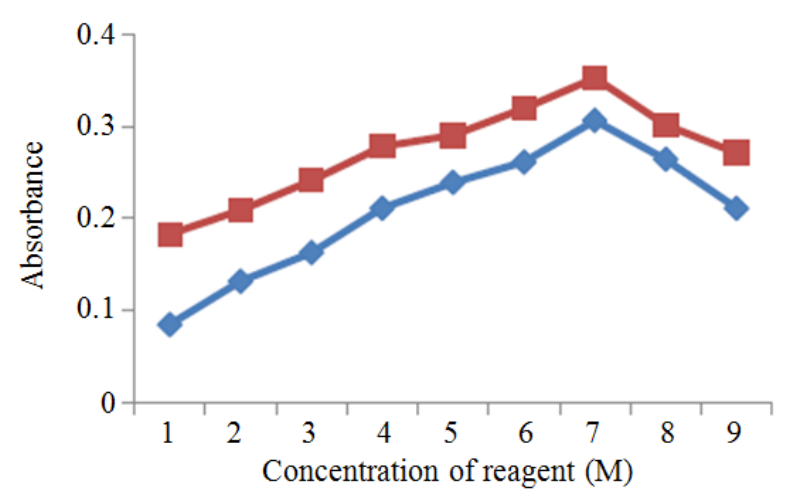

Fig. 8. Effect of HTMCDAP concentration on the cloud point extraction of $\mathrm{Mn}^{+2}=16 \mu \mathrm{g} \mathrm{L}^{-1}$ and $\mathrm{Hg}^{+2}=14 \mu \mathrm{g} \mathrm{L}^{-1}, 1$ $0.8 \mathrm{~mL} \mathrm{10 \% (V/V)} \mathrm{(Triton} \mathrm{X-100),} \mathrm{pH}=7$

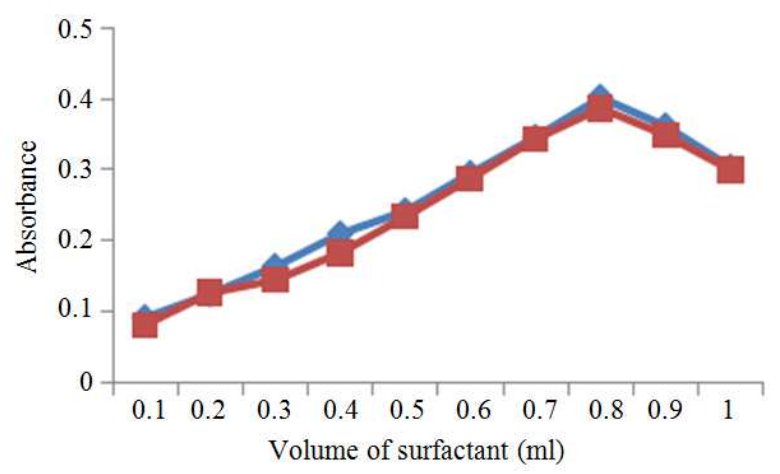

Fig. 9. Effect of volume $10 \%(\mathrm{v} / \mathrm{v})$ TritonX-100 on the cloud point extraction of $\mathrm{Mn}+2=16 \mu \mathrm{g} \mathrm{L}^{-1}$ and $\mathrm{Hg}^{+2}=14 \mu \mathrm{g}$ $\mathrm{L}^{-1}, \mathrm{HTMCDAP}=7 \times 10^{-5} \mathrm{Mol} \mathrm{L}^{-1} \mathrm{pH}=7$

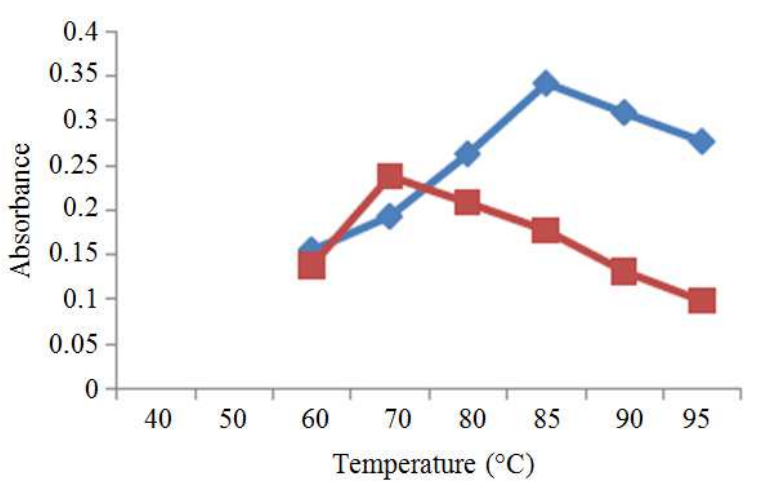

Fig. 10. Effect of the temperature on the cloud point extraction of $\mathrm{Mn}^{+2}=16 \mu \mathrm{g} \mathrm{L}^{-1}$ and $\mathrm{Hg}^{+2}=14 \mu \mathrm{g} \mathrm{\textrm {L } ^ { - 1 }}$, $\mathrm{HTMCDAP}=7 \times 10^{-5} \mathrm{Mol} \mathrm{L}^{-1} \mathrm{pH}=7$

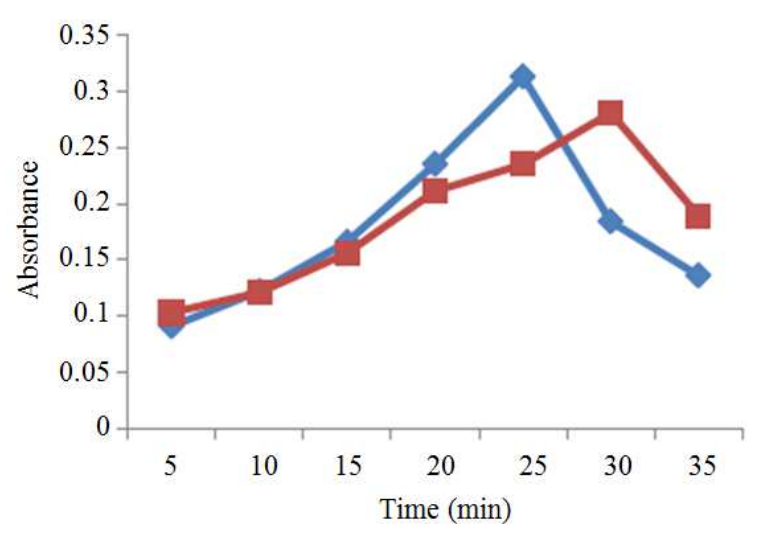

Fig. 11. Effect the incubation of time on the cloud point extraction of $\mathrm{Mn}^{+2}=16 \mu \mathrm{g} \mathrm{L}^{-1}$ and $\mathrm{Hg}^{+2}=14 \mu \mathrm{g} \mathrm{L}^{-1}$, $\mathrm{HTMCDAP}=7 \times 10^{-5} \mathrm{Mol} \mathrm{L}^{-1} \mathrm{pH}=7$

Table 3. Effect of Interference ions

\begin{tabular}{lll}
\hline $\begin{array}{l}\text { Interfering } \\
\text { ion }\end{array}$ & $\begin{array}{l}\text { Amount } \\
\text { added } \mu \mathrm{g} \mathrm{L}^{-1}\end{array}$ & $\begin{array}{l}\text { Percentage of Interference } \\
(\%) \text { of reagent }\end{array}$ \\
\hline $\mathrm{K}^{+}$ & 150 & +2.88 \\
$\mathrm{Na}^{+}$ & 150 & +4.52 \\
$\mathrm{Ca}^{+2}$ & 150 & +10.6 \\
$\mathrm{Mg}^{+2}$ & 150 & +7.40 \\
$\mathrm{SCN}^{-}$ & 150 & -5.3 \\
$\mathrm{Br}^{-}$ & 150 & --12.75 \\
$\mathrm{So}_{4}{ }^{-2}$ & 150 & -14.4 \\
$\mathrm{I}^{-}$ & 150 & --9.0 \\
$\mathrm{Cr}_{2} \mathrm{O}_{7}^{-2}$ & 150 & 100 \\
\hline
\end{tabular}

Table4. Analytical characteristics data of the proposed method

\begin{tabular}{lll}
\hline Parameter & $\mathrm{Hg}(\mathrm{II})$ & $\mathrm{Mn}(\mathrm{II})$ \\
\hline$\chi_{\max }$ & $423 \mathrm{~nm}$ & $444 \mathrm{~nm}$ \\
$\mathrm{R} 2$ & 0.9982 & 0.9961 \\
$\mathrm{RSD}$ & $1.3 \%$ & $1.4 \%$ \\
Linear rang & $2-14 \mu \mathrm{g} \mathrm{L}^{-1}$ & $2-16 \mu \mathrm{g} \mathrm{L}^{-1}$ \\
Recovery & $96-98.7 \%$, & $97-99.7 \%$ \\
Limit of detection & $0.75 \mu \mathrm{g} \mathrm{L}^{-1}$ & $0.4 \mu \mathrm{g} \mathrm{L}^{-1}$ \\
Slope & 0.0278 & 0.0252 \\
Intercept & 0.0144 & 0.0129 \\
\hline
\end{tabular}




\section{Accuracy and Precision}

The accuracy and precision of proposed methods were determined $\mathrm{Hg}$ (II) and $\mathrm{Mn}$ (II) at two concentration level of by analyzing eight replicate sample of each concentration. Table 5 show high reproducibility of results and precision of the methods.

\section{Analytical Application}

The proposed methods was applied to the quantitative determination of $\mathrm{Hg}$ (II) and $\mathrm{Mn}$ (II) in wastewater of Rustimiyah city in Iraq. It was gave a good accuracy and precision as shown in Table 6.

Table 5. Accuracy and precision of proposed methods

Amount of $\mathrm{Hg}(\mathrm{II}) \mu \mathrm{g} \mathrm{L} \mathrm{L}^{-1}$

\begin{tabular}{lccc}
\hline Present & Found & RSD (\%)* & Recovery (\%) \\
\hline 14 & 13.78 & 1.40 & 96.0 \\
6 & 5.88 & 1.20 & 98.7 \\
Amount of $\mathrm{Mn}(\mathrm{II}) \mu \mathrm{g} \mathrm{L}^{-1}$ & & & 97.0 \\
16 & 15.87 & 1.55 & 99.7 \\
6 & 5.91 & 1.30 & \\
\hline
\end{tabular}

*Average of eight determination

Table 6. Application of proposed method for determination $\mathrm{Hg}$ (II) and $\mathrm{Mn}$ (II)

\begin{tabular}{|c|c|c|c|c|c|c|c|}
\hline & Real sample & Taken & Found & $\mathrm{RSD}(\%) *$ & $\begin{array}{l}\text { RSD \% } \\
\text { average }\end{array}$ & $\begin{array}{l}\text { Recovery } \\
(\%)\end{array}$ & $\begin{array}{l}\text { Recovery } \\
(\%) \text { average }\end{array}$ \\
\hline \multirow{3}{*}{$\mathrm{Hg}(\mathrm{II})$} & Wastewater (input)of Rustimiyah city & 14 & 13.880 & 0.8 & 0.65 & 99.0 & 97.5 \\
\hline & & 6 & 5.760 & 0.5 & & 96.0 & \\
\hline & Wastewater (output) of Rustimiyah city & 14 & 13.650 & 0.9 & 0.80 & 97.5 & 95.0 \\
\hline \multirow{5}{*}{$\mathrm{Mn}(\mathrm{II})$} & & 6 & 5.590 & 0.7 & & 93.0 & \\
\hline & Wastewater (input)of Rustimiyah city & 16 & 16.051 & 1.1 & 0.95 & 100.0 & 100.0 \\
\hline & & 6 & 6.049 & 0.8 & & 100.0 & \\
\hline & Wastewater (output) of Rustimiyah city & 16 & 16.059 & 1.3 & 0.95 & 100.0 & 100.5 \\
\hline & & 6 & 6.061 & 0.6 & & 101.0 & \\
\hline
\end{tabular}

Table 7. Comparison of the proposed method with reported methods for the preconcentration and CPE of $\mathrm{Hg}$ (II) and Mn(II)

\begin{tabular}{|c|c|c|c|c|c|c|c|}
\hline Element & Chelating agent & Surfactant & Technique & Linear range & $\mathrm{RSD} \%$ & The detection limits & Ref. \\
\hline $\operatorname{Mn}(\mathrm{II})$ & PMBP & TritonX-100 & FAAS & & & $1.45 \mathrm{ng} \mathrm{mL}^{-1}$ & Sun et al. (2006) \\
\hline $\mathrm{Hg}(\mathrm{II})$ & PAN & TritonX-114 & & & - & 1.65 & Ulusoy et al. (2012) \\
\hline $\mathrm{Mn}(\mathrm{II})$ & TAN & TritonX-114 & 0.28 & & & & Toe and Chen (2001) \\
\hline $\mathrm{Mn}(\mathrm{II})$ & MPBIM & Triton X-114 & AAS & & & 1.47 & Shokrollahi et al. (2011) \\
\hline $\mathrm{Hg}(\mathrm{II})$ & Methyl green & TritonX-100 & ICP-OES & & & 0.065 & $\mathrm{Li}$ and $\mathrm{Hu}(2007)$ \\
\hline $\mathrm{Hg}(\mathrm{II})$ & 3-NBT & TritonX-114 & ICP-OES & & & 0.48 & Shoaee et al. (2012) \\
\hline $\mathrm{Mn}(\mathrm{II})$ & $\begin{array}{l}\text { 2-[2'-(6-methylben- } \\
\text { zothiazolylazo })]-4- \\
\text { bromophenol }\end{array}$ & TritonX-100 & FI-FAAS & & & 0.70 & Lemos and David (2010) \\
\hline $\operatorname{Hg}($ II) $\mathrm{Mn}(\mathrm{II})$ & HTMCDAP & TritonX-100 & UV/VIS & $\begin{array}{l}2-14 \mu \mathrm{g} \mathrm{L}^{-1} \\
2-16 \mu \mathrm{g} \mathrm{L}^{-1}\end{array}$ & $\begin{array}{l}1.3 \% \\
1.4 \%\end{array}$ & $\begin{array}{l}0.75 \mu \mathrm{g} \mathrm{L}^{-1} \\
0.4 \mu \mathrm{g} \mathrm{L}^{-1}\end{array}$ & $\begin{array}{l}\text { Proposed } \\
\text { methods }\end{array}$ \\
\hline
\end{tabular}

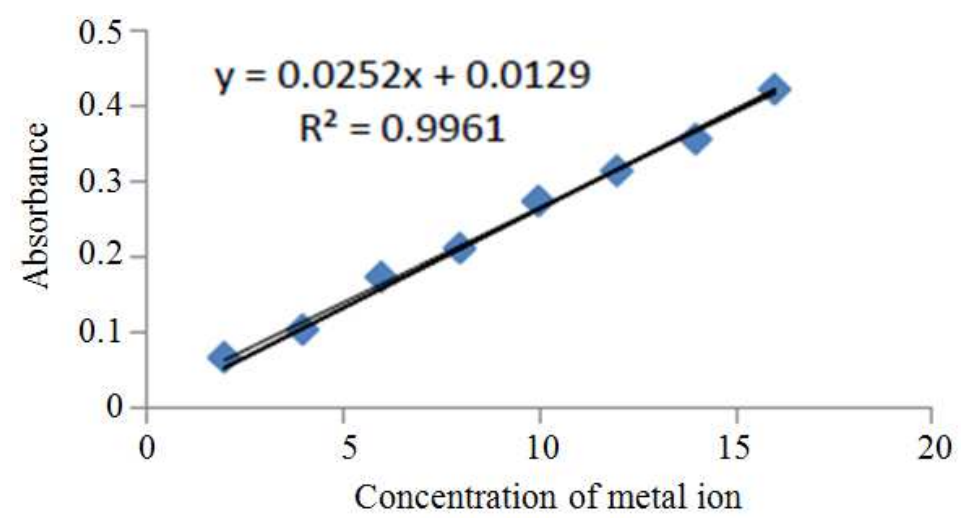

Fig. 12. Calibration graph of Mn(II) 


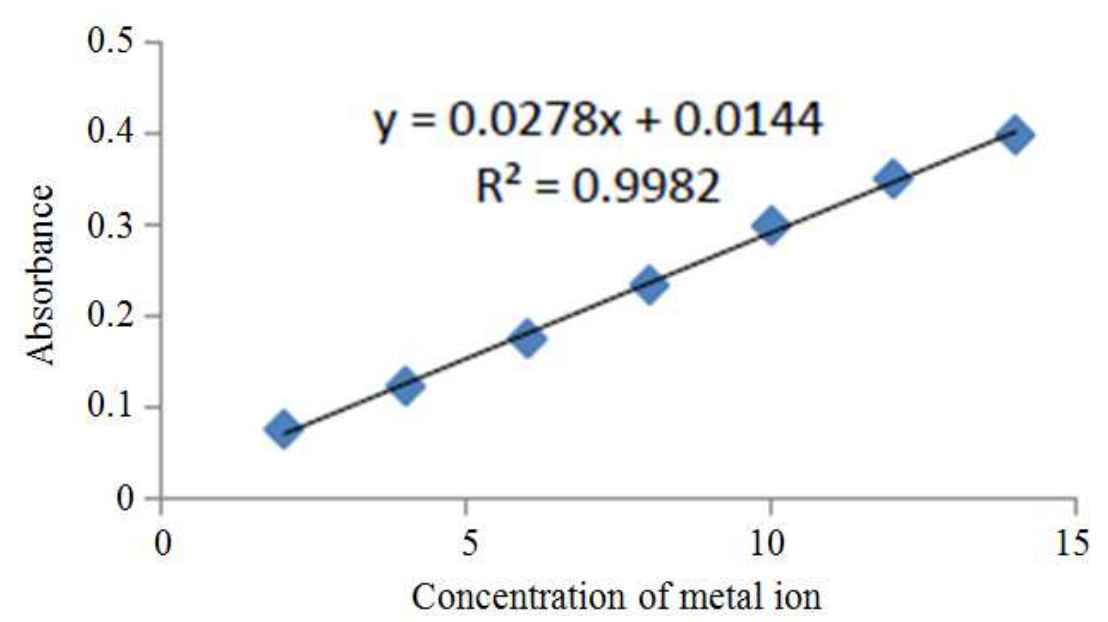

Fig. 13. Calibration graph of $\mathrm{Hg}$ (II)

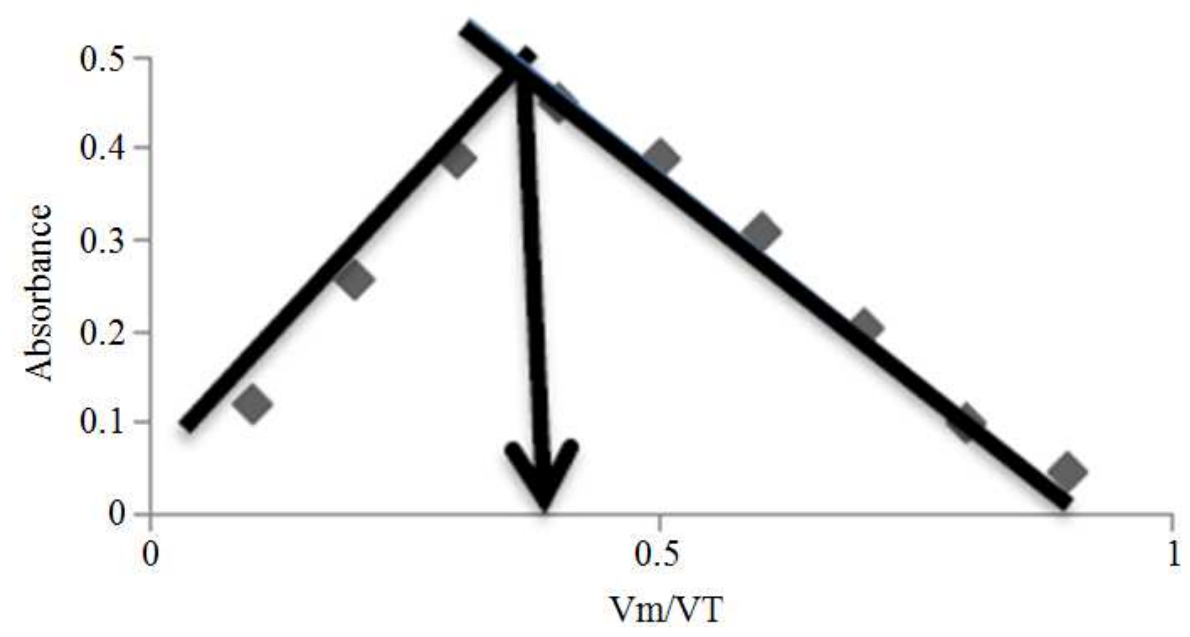

Fig. 14. Continuous variation of $\mathrm{Hg}^{+2}$-HTMCDAP

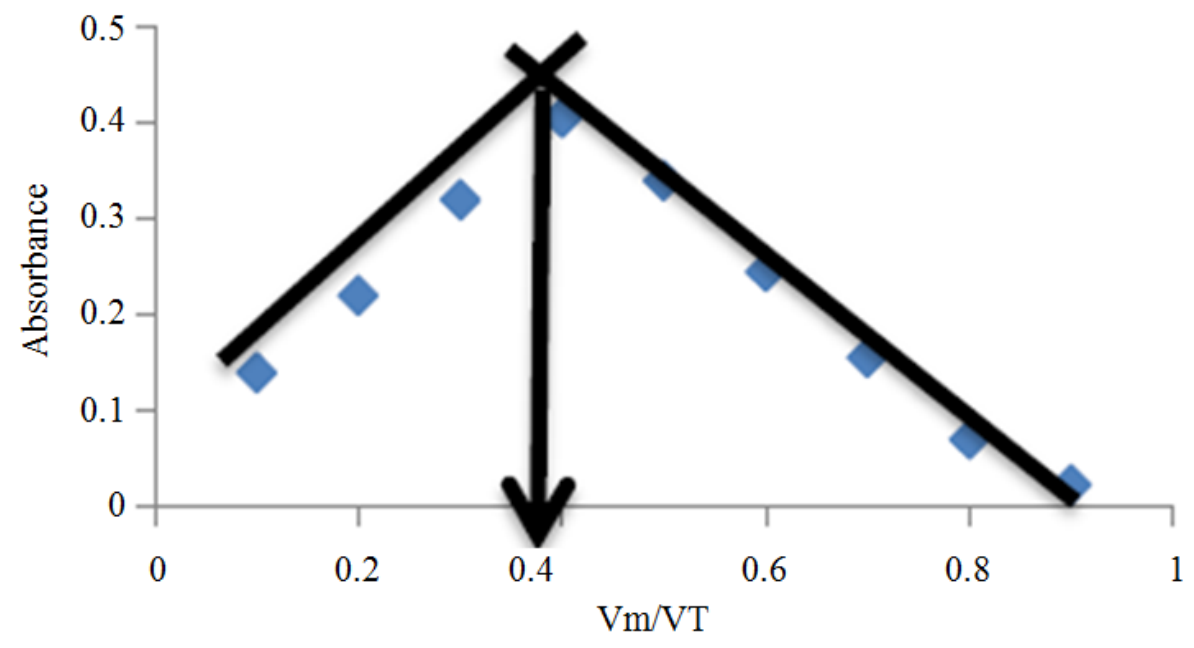

Fig. 15. Continuous variation of $\mathrm{Mn}^{+2}$-HTMCDAP 


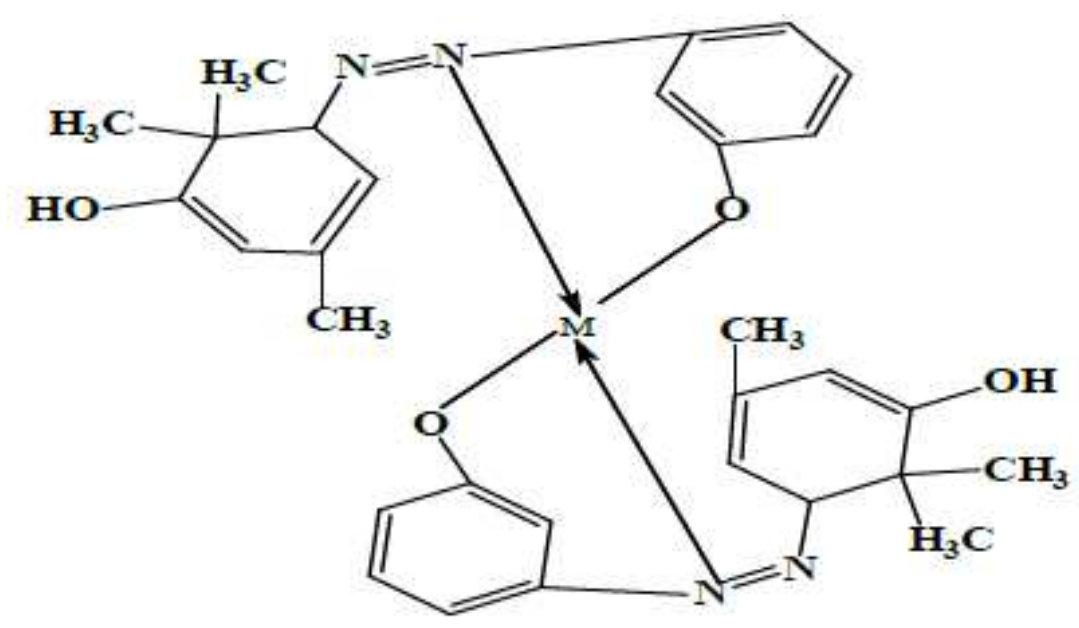

Scheme2. The predictable structure of $\mathrm{Mn}^{+2}-\mathrm{HTMCDAP}$ and $\mathrm{Hg}^{+2}-\mathrm{HTMCDAP}$

\section{Conclusion}

Cloud point extraction is cheapens, easy, safe and versatile pre-concentration technique to determine $\mathrm{Hg}$ (II) and $\mathrm{Mn}(\mathrm{II})$ by UV/VIS. In proposed method the ligand HTMCDAP is a sensitivity and selectivity for determination of $\mathrm{Hg}(\mathrm{II})$ and $\mathrm{Mn}$ (II) in wastewater sample and gave a good RSD and low limit of detection.

\section{Acknowledgment}

I would like to acknowledge my chemistry department college science for women, university of Baghdad for support me for the study.

\section{Ethics}

This article is original and contains unpublished material. The corresponding author confirms that all of the other authors have read and approved the manuscript and no ethical issues involved.

\section{References}

Ahmad, F., K. Niknam, I.E. Niknam, S. Delavari and A. Khanmohammadi, 2011. Cloud point extraction and determination of silver ion in real sample using Bis((1H-benzo[d ]imidazol-2yl)methyl)sulfane. Chemistry, 8: 435-442. DOI: 10.1155/2011/180476

Al-Bayati, S.M., E.M. Rasheed, M.A. Al-Soodani and S.M. Salah, 2013. Synthesis, characterization and stability study of V(IV), Zr(IV), Rh ( I II), Pd (II), $\mathrm{Cd}(\mathrm{II})$ and $\mathrm{Hg}(\mathrm{II})$ complexes with pyrazol derivative. Baghdad Sci. J., 11: 1592-1603.

Bakir, S.R. and S.A. Dhahir, 2013. Cloud point extraction spectrophotometric determination of trace amounts of nickel by SALEN as reagent in waste water of Iraq. Int. Interdisciplinary Res. J., 3: 9-21.
Chen, J. and K.C. Toe, 2001. Determination of cadmium, copper, lead and zinc in water samples by flame atomic absorption spectrometry after cloud point extraction. Anal. Chim. Acta, 450: 215-222. DOI: 10.1016/S0003-2670(01)01367-8

Dhahir, S.A. and S. RhajabBakir, 2015. Cloud point extraction spectrophotometric determination of nickel, copper, cobalt and chromium by 4- HBDA1, 5DPHP as reagent in wastewater of Iraq. Environ. Sci., 10: 150-160.

Doroschuk, V.O., S.O. Lelyushok, V.B. Ishchenko and S.A. Kulichenko, 2004. Flame atomic absorption determination of manganese(II) in natural water after cloud point extraction. Talanta, 64: 853-856. DOI: 10.1016/j.talanta.2004.03.056

Kirkan, B. and R. Gup, 2008. Synthesis of new azo dyes and copper(II) complexes derived from barbituric acid and 4-aminobenzoylhydrazone. Turk. J. Chem., 32: 9-17.

Lemos, V.A. and G.T. David, 2010. An on-line cloud point extraction system for flame atomic absorption spectrometric determination of trace manganese in food samples. Microchemcal J., 94: 42-47. DOI: 10.1016/j.microc.2009.08.008

Li, Y. and B. Hu, 2007. Sequential cloud point extraction for the speciation of mercury in seafood by inductively coupled plasma optical emission spectrometry. Spectrochimica Acta Part B: Atomic Spectrometry, 62: 1153-1160.

DOI: $10.1016 /$ j.sab.2007.07.005

Manzoori, J.L. and H. Abodlmohammad-Zadeh, 2007. Extraction and preconcentration of lead using cloud point methodology: Application to its determination in real samples by flame atomic absorption spectrometry. Acta Chim. Slov., 54: 378-384. 
Manzoori, J.L. and A. Bavili-Tabrizi, 2002. The application of cloud point preconcentration for the determination of $\mathrm{Cu}$ in real samples by flame atomic absorption spectrometry. Microchem. J., 72: 1-7. DOI: 10.1016/S0026-265X(01)00113-8

Mohammed, I.A. and M. Asniza, 2010. Synthesis of new azo compounds based on N-(4hydroxypheneyl)maleimide and N-(4methylpheneyl)maleimide. Molecules, 15: 7498-7508. DOI: $10.3390 /$ molecules 15107498

Nakamoto, K., 1997. Infrared and Raman Spectra of Inorganic and Coordination Compounds, Theory and Applications in Inorganic Chemistry. 5th Edn., Wiley, ISBN-10: 0471163945, pp: 408.

Portugal, L.A., H.S. Ferreia, W.N.L. dos Santos and S.L.C. Ferreia, 2007. Simultaneous preconcentration procedure for the determination of cadmium and lead in drinking water employing sequential multi-element flame atomic absorption spectrometry. Microchim. J., 87: 77-80.

DOI: 10.1016/j.microc.2007.05.008

Roundhill, D.M., I.B. Solangi, S. Memon, M.I. Bhanger and M. Yilmas, 2009. The liquid liquid extraction of toxic metals $(\mathrm{Cd}, \mathrm{Hg}$ and $\mathrm{Pb})$ by calixarenes. Pak. J. Anal. Environ. Chem., 10: 1-13.

Scarmoutzos, L.M. and O.E. Boyd, 2004. Environmental and toxicological concerns of dental amalgam and mercury. MVS Solutions, Inc.

Shoaee, H., M. Roshdi, N. Khanlarzadeh and A. Beiraghi, 2012. Spectrochim. Acta Part A: Molecular Biomolecular Spectroscopy, 98: 70-75. DOI: $10.1016 /$ j.saa.2012.08.027

Shokrollahi, A., H. Tavallali, Z. Montaseri and K. Nikanam, 2011. Using an indol derivative as complexing agent for cloud point preconcentration and determination of magnesium and silver ions in various samples by faas. J. Chil. Chem. Soc., 2011, 57: 1134-1139.

DOI: $10.4067 / S 0717-97072012000200017$

Sun, Z., P. Liang, Q. Ding and J. Cao, 2006. Cloud point extraction preconcentration of manganese(II) from natural water samples using 1-phenyl-3-methyl-4benzoyl-5-pyrazolone and triton X-100 and determination by flame atomic absorption spectrometry. Anal. Sci., 22: 911-913.

DOI: 10.2116/analsci.22.911
Toe, K.C. and J. Chen, 2001. Determination of manganese in water samples by flame atomic absorptionspectrometry after cloud point extraction. Analyst, 126: 534-537. DOI: 10.1039/B008717N

Ulusoy, H.I., R. Gurkan and S. Ulusoy, 2012. Cloud point extraction and spectrophotometric determination of mercury species at trace levels in environmental samples. Talanta, 88: 516-523. DOI: $10.1016 /$ j.talanta.2011.11.026

Veerachalee, N., V. P. Taweema and A. Songsasen, 2007. Complexation and spectrophotometric determination of cobalt(II) ion with 3-(2'thiazolylazo)-2,6-diaminopyridine. Kasetsart J. (Nat. Sci.), 41: 675-680.

Velasco-Ryenolda, C., M. Navarro-Alarcón, H.L.G. De La Serranaa, V. Perez-Valero and M.C. LopezMartinez, 2008. Total and dialyzable levels of manganese from duplicate meals and influence of other nutrients: Estimation of daily dietary intake. Food Chem., 109: 113-121.

DOI: 10.1016/j.foodchem.2007.12.025

Wuilloud, G.M., J.C.A. de Wuilloud, R.G. Wuilloud, M.F. Silva and R.A. Olsina et al., 2002. Cloud point extraction of vanadium in parenteral solutions using a nonionic surfactant (PONPE 5.0) and determination by flow injection-inductively coupled plasma optical emission spectrometry. Talanta, 58: 619-627. DOI: 10.1016/S0039-9140(02)00366-1

Yang, G., Z. Xia, Y. Wu, H. Sun and J. Yin, 2004. Study on the solid phase extraction of $\mathrm{Hg}(\mathrm{II})$-SBDTR chelate with $\mathrm{C}_{18}$ disks and its application to the determination of mercury in tobacco and tobacco additive. Bull. Korean Chem., 25: 549-553.

Youcef, M.H., T. Benabdallah and H. Ilikti, 2006. A study on copper (II) extraction from sulphate medium via cloud- point extraction with $\mathrm{N}$ salicylideneaniline ligand in presence of nonionic surfactant. Can. J. Anal. Sci. Spect., 51: 267-277. 